EGU2020-8820, updated on 24 Sep 2020

https://doi.org/10.5194/egusphere-egu2020-8820

EGU General Assembly 2020

(c) Author(s) 2020. This work is distributed under

the Creative Commons Attribution 4.0 License.

\title{
Deriving water content from multiple geophysical properties of a firn aquifer in Southeast Greenland
}

Siobhan Killingbeck ${ }^{1}$, Nicholas Schmerr ${ }^{2}$, Lynn Montgomery ${ }^{3}$, Adam Booth ${ }^{1}$, Phil Livermore ${ }^{1}$, Jonathan Guandique ${ }^{2}$, Olivia Miller ${ }^{4}$, Scott Burdick ${ }^{5}$, Richard Forster ${ }^{6}$, Lora Koenig ${ }^{7}$, Anatoly Legchenko ${ }^{8}$, Stefan Ligtenberg ${ }^{9}$, Clément Miège ${ }^{6}$, Kip Solomon $^{10}$, and Landis West ${ }^{1}$

${ }^{1}$ The University of Leeds, School of Earth and Environment, IAG, Leeds, United Kingdom of Great Britain and Northern Ireland (eespr@leeds.ac.uk)

${ }^{2}$ Department of Geology, University of Maryland, College Park, USA

${ }^{3}$ Atmospheric and Oceanic Sciences Department, University of Colorado Boulder, Boulder, USA

${ }^{4}$ Utah Water Science Center, United States Geological Survey, USA

${ }^{5}$ Department of Geology, Wayne State University, Detroit, USA

${ }^{6}$ Department of Geography, University of Utah, Salt Lake City, USA

${ }^{7}$ National Snow and Ice Data Center, Boulder, USA

${ }^{8}$ Laboratoire d'etude des Transferts en Hydrologie et Environment, Institute of Research for Development, Grenoble, France

${ }^{9}$ Institute for Marine and Atmospheric Research Utrecht, Utrecht University, Utrecht, The Netherlands

${ }^{10}$ Department of Geology and Geophysics, University of Utah, Salt Lake City, USA

Warming of the polar ice sheets causes changes in the hydrological regime of surface layers of firn and ice. Surface meltwater may undergo perennial storage of liquid water above the firn-ice transition, which could slow sea level rise or cause sudden release events, when storage capacity is reached. Firn aquifers have been commonly observed within the lower percolation zone of the southeastern Greenland ice sheet during the past decade, and more recently, across some Antarctic ice shelves. Knowledge of the geographic extent and fractional liquid water content (and storage) of such aquifers will enable a better understanding of their effects on the sub- and englacial hydrologic system and is crucial for accurate predictions of the contribution of meltwater discharge to global sea level rise.

Quantitative geophysical analysis from surface observations can be used to infer hydrological properties of the firn and ice without time intensive direct drilling, providing an efficient spatial distribution of properties along with an estimate of their uncertainty. Furthermore, by combining multiple types of geophysical observations, joint inversions allow ambiguities of one methodology to be mitigated by resolution in the other.

Here, we demonstrate that this joint approach is a powerful complement to the conventional geophysical analysis of firn aquifers, by combining seismic, ground penetrating radar and borehole data to characterise aquifer properties, using the 'MuLTI' algorithm. In particular, we incorporate seismic shear wave velocities (Vs), derived from surface (Rayleigh) waves offering a 
promising means of distinguishing zones containing liquid water, into independent compressional wave velocity, density, and radar soundings of the water table. We find Vs decreases from 1600 $\mathrm{m} / \mathrm{s}$ in the unsaturated firn above the water table at around $15 \mathrm{~m}$ depth, to $800 \mathrm{~m} / \mathrm{s}$ through saturated 'clean' firn aquifer at around $25 \mathrm{~m}$ depth. However, at lower elevations, Vs increases to $1250 \mathrm{~m} / \mathrm{s}$ through thicker, older firn aquifer where there are many ice lenses, which are interpreted to correspond with episodes of refreezing aquifer water as the system has evolved through time. With access to multiple seismic wave velocities (compressional and shear) through the aquifer, a more accurate estimate of liquid water content can be derived. Thus, the application of the MuLTI algorithm to this pressing new problem can deliver an accurate assessment of firn aquifer properties, and provide clear uncertainty limits which will be valuable for predictive modelling.

How to cite: Killingbeck, S., Schmerr, N., Montgomery, L., Booth, A., Livermore, P., Guandique, J., Miller, O., Burdick, S., Forster, R., Koenig, L., Legchenko, A., Ligtenberg, S., Miège, C., Solomon, K., and West, L.: Deriving water content from multiple geophysical properties of a firn aquifer in Southeast Greenland, EGU General Assembly 2020, Online, 4-8 May 2020, EGU2020-8820, https://doi.org/10.5194/egusphere-egu2020-8820, 2020 